\title{
Rare Earths in Geological Formations of Central Region of the Dniester River Basin, Republic of Moldova
}

\author{
Aurelia Popuiac \\ State University of Moldova, 60/3 Gh. Asachi Street, 2028 Chişinău, Moldova \\ Correspondence should be addressed to Aurelia Popuiac; apopuiac@gmail.com
}

Received 25 September 2014; Accepted 16 November 2014

Academic Editor: Giovanni Martinelli

Copyright (C) 2015 Aurelia Popuiac. This is an open access article distributed under the Creative Commons Attribution License, which permits unrestricted use, distribution, and reproduction in any medium, provided the original work is properly cited.

\begin{abstract}
In the different varieties of crystalline basement of Archean and Proterozoic age and in Vendian (Ediacaran) basal layers of platform coverture in the Central Basin of the Dniester River were found relatively high concentrations of Lanthanum, Cerium, Yttrium, Ytterbium, and Scandium. Because the petrographic formations, which are genetic associated with RE elements in Dniester region are absent, the origin of these elements is unclear. At the same time, in the geological mapping, it was detect that geochemical aureoles of REE, found in the northern region of Republic of Moldova, are generated by accessory minerals monazite and zircon present in the rock of basement platform and fragments of crystalline rock in the composition of terrigenous formations from basal levels of sedimentary coverture. Probably mentioned minerals are brought from Ukrainian Crystalline Shield regions, in which are spread varieties of granitic rocks and alkaline pegmatite. It is not excluded that in these basal layers in the sedimentogenes processes and differentiation of detrital material to be formed the mechanic aureoles rich in monazite and zircon, which in turn can form significant concentrations of rare earths. To solve the perspective problem of detection of industrial mineral accumulations of RE in the central region of the Dniester River basin, it is necessary to conduct within this area detailed geological and geochemical research.
\end{abstract}

\section{Introduction}

During the years 1982-1992, several special geological researches were carried out in the north-eastern part of the Republic of Moldova with the purpose of determining the metallogenetic features in this area. The central basin of the Dniester River has already been considered perspective in terms of detecting mineralizations of the radioactive elements, rare metals, iron, zinc, lead, and barite, including the rare earths. In many varieties of crystalline basement rocks and basal layers of sedimentary cover were found relatively high concentrations of rare earths (RE) - Lanthanum, Cerium, Yttrium, Ytterbium, and Scandium.

At the time of undertaking the geological mapping works at scale 1:200000 (1947-1952) in the whole European territory of ex-USSR, sedimentary formations in the northern part between the rivers Dniester and Prut had already been differentiated, and in outcrops of the river Dniester's bed (village Cosauti, Soroca) had been started first researches of crystalline rocks in cropping. At the same time with geological mapping were effectuated works of prospecting and exploring useful mineral deposits. Information on previous geological works is included in the publication "Geology of USSR, Vol XLV” [1].

In terms of methodology, all preliminary prospecting works were based on drilling carried out in areas of gravitational and magnetic anomalies, considered by many researchers anomalies generated by disturbed geological bodies which may contain useful mineral deposits. In most cases, the drillings crossed the rocks that contained quite small concentrations of useful components, situated nearby the sensitivity threshold of chemical analyses. Therefore, the undertaking of some detailed geological works in the specified region had not been sufficiently argued.

Geological mapping of Precambrian formations of the crystalline basement and the basal layer of sedimentary cover, effectuated on a territory with a relatively limited area (Figure 1), were continued by a group of researchers from the 


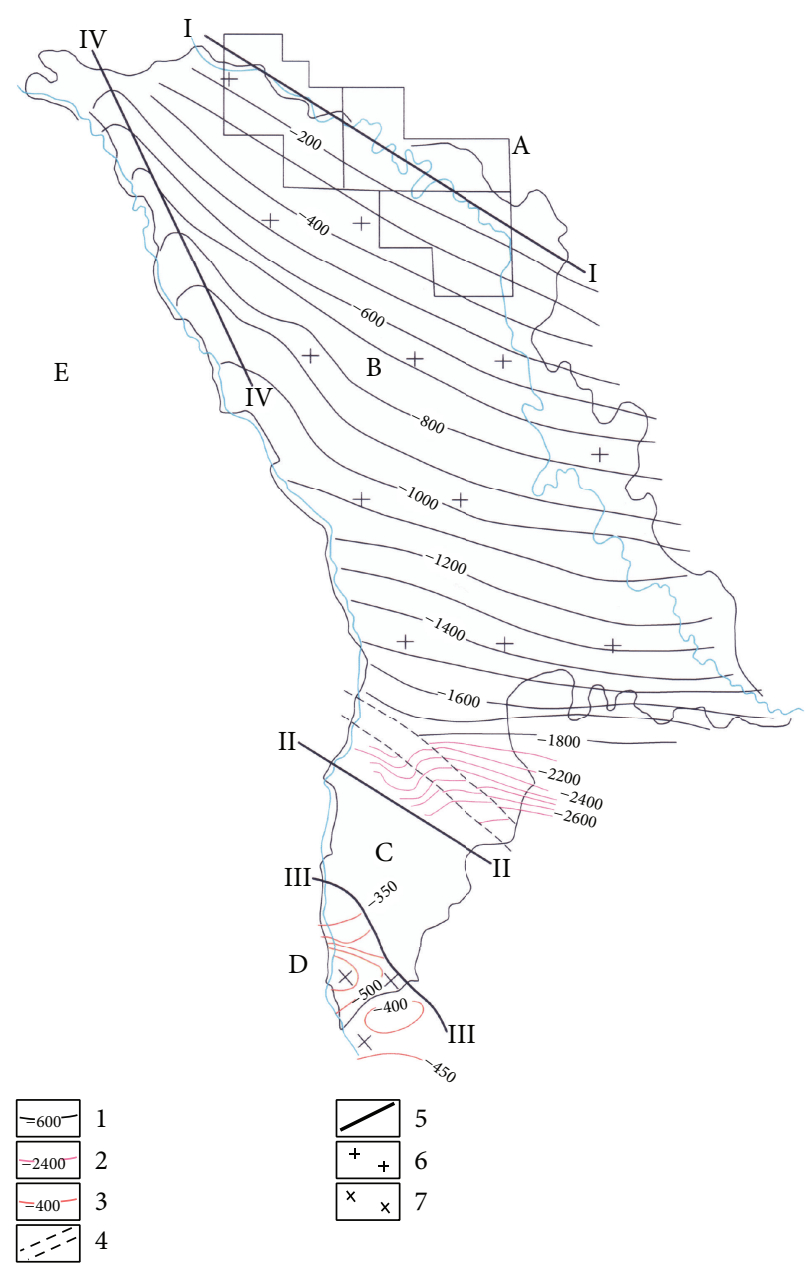

FIGURE 1: Schematic map of geological structure of the Republic of Moldova [1]; 1-isohypses of Precambrian crystalline basement constructed on basis of drillings; 2-isohypses of Precambrian crystalline basement constructed on basis of geophysical prospecting; 3-isohypses of Hercynian crystalline basement constructed on basis of drillings; 4-zone of maximal gravitational gradients; 5-tectonic disjunctions; 6-Precambrian crystalline rocks; 7-Metamorphosed rocks of early Paleozoic age; I-I Dniester Fault; II-II Ciadar-Lunga Fault; III-III Cahul-Ismail Fault; IV-IV Ciuhur Fault; A-Ukrainian Crystalline Shield region; B-slope of Southwestern East European Platform; CThe Predobrogean Depression; D-north-west region of the Dobrogea Orogen; E-South West region of the Precarpathian Depression.

ex-Geological Department of MSSR (now Agency of Geological Mineral Resources of Moldova-AGRM): A. Zaharov, V. Sergheev, V. Ciobotaru, E. Hiora, G. Fedorenko, and so forth. Because of changes that followed the proclamation of the Independence of the Republic of Moldova, the researches which had to be executed in a more detailed way were not run to a successful end. To some extent the geological data and the issues addressed in this chapter are unique, because we are not sure that in the near future in Dniester region such works will be undertaken.

Study of the composition and origin of geological formations of Archean-Proterozoic basement allowed following the evolution of substance from the earth crust, beginning from the moment of accumulation until hypergen modification stages of rocks in conditions of the platform.

Both in the process of geological study in the field and in the process of elaborating this chapter, all corresponding materials, edited or available in AGRM funds, have been examined with great attention.
Some rather general concepts about the geological structure of crystalline formations, covered by much younger complex sedimentary layers, were elaborated based on data from drillings executed in different years with the purpose of geological mapping, geological, and hydrogeological prospections. On the territory between the rivers Dniester and Prut during about four decades were executed a large number of drillings, majority of which also crossed the basement rocks in the northern part of country. As a rule, drillings were undertaken only for research purposes of sedimentary rocks and because of this the opening depths of Archean and Proterozoic rocks of crystalline formations ranged between about 20 and 50 meters. Having at disposition a great number of cores, it was possible to research only composition of crystalline rocks from the surface of Precambrian basement. There had been several attempts on the basis of the drilling and geophysical prospecting to elaborate the geological maps of some portions of the crystalline basement surface $[2,3]$ and the layers of sedimentary rocks of the lower levels of 
platform cover [4], but all such geological deductions have proved to be arbitrary, often subjective and presented more a personal vision of researchers on the geology of earth crust in this area [5]. Also rather approximately had been executed the geological prospectings in order to solve the perspective of detection in the mentioned region of some significant accumulation of rare earth elements [6].

The proposed study is one of a synthesis of geological results performed by a group of researchers who have worked together, beginning with the design, field research, and laboratory analyses and ending with the generalization of obtained data. In this regard, the author presents not only the geological vision of this group but also his own concept concerning the specificity of rare earths in the region of Moldovan segment of Dniester basin.

\section{General Suggestions Concerning the Geological Structure of the Territory of the Republic of Moldova}

On the territory of the Republic of Moldova are distinguished several fragments of some regional structures, which in terms of tectonic and geological evolution are different from each other in a highlighted manner [8].

About two thirds of the territory of the republic falls in a segment of southwest pericratonic zone of the East European Platform, called by Moldavian and Ukrainian geologists the "Moldavian Plate" (Figure 1).

A part of south-eastern region is occupied by a fragment of the Dobrogea Orogen, which endorses the typical features of a young platform. Constituted in late Paleozoic it is considered an epi-Hercynian platform. Crystalline basement is constituted by metamorphosed rocks in lower metamorphic faces and igneous intrusions, and sedimentary cover about 500 meters thick is formed by Mesozoic-Cainozoic age strata placed almost parallel.

Another regional structure-Predobrogean Depression, which extends to the northwest in Romania-is seen by some researchers [9] as a component part of the East European Platform. At the same time, the geological evolution of this structure and tectonic processes which manifested themselves in the Paleozoic and especially in the early Mesozoic, allow considering the Predobrogean Depression an independent structure with specific geological and structural features.

In the northern and north-eastern regions of the Republic of Moldova (marked area in Figure 1) we can highlight three geological-structural units: crystalline basement, sedimentary cover composed of diverse rocks, and PliocenePleistocene formations. These three geological-structural units in terms of age, origin, and composition are different from each to other in a cardinal way. Due to shallow depths up to crystalline rocks of the basement and mineralization which contain elements of rare earths, discovered in the basal layers of sedimentary cover, the central region of the Dniester River basin has always made up a remarkable object of study for geological research.

\section{The Petrographic Specificity of the Crystalline Basement Rocks}

The principle of differentiation of crystalline rocks, in most cases Archean or of early Proterozoic age, situated in the basement composition, was and remains a subject of permanent discussion. In geochronological-stratigraphic terms the most appropriate methodological principle in the geological study of the south-western slope of the East European Platform is the correlation of ultrametamorphosed crystalline formations within a regional or local geotectonic unit. Basement rocks in the area reflect all the specific features of geological processes that led to the formation of the south-western slope of the Ukrainian Crystalline Shield, which is situated to the north of the Dniester Fault-the most important geotectonic element from the mentioned region (Figure 1). Crystalline basement is an agglomerate composed of metamorphic, ultrametamorphic, magmatic, and metasomatic rocks of different ages-early Archean and early Proterozoic. In general, crystalline formations are presented in an extremely complicated way, but at the same time there are some distinguishing features that differentiate this portion of the earth crust from other neighbouring areas. Analyzing the magmatic and ultrametamorphic processes, which occurred in the Precambrian of Ukrainian Crystalline Shield, Archean and Proterozoic rocks and can be systematized in specific formations that differ from each other by petrographic varieties and physicochemical conditions of their formation [10]: gneisses and crystalline schists (early Archean age); enderbites, plagiomigmatites, plagiogranites (formed as a result of anatexis processes at the geochronological limit of later Archean-early Proterozoic); alaskites, leucogranites (early Proterozoic age of palingenesis origin)Table 1 . Having a predominantly granitic composition these varieties of rocks differ from each other only in the auxiliary index (accessory mineralizations, presence of geochemical aureoles, and geophysical anomalies). It should be mentioned that in the composition of these rocks, with rare exceptions, predominate plagioclases (oligoclase-andesine) and almost in all lithological varieties often in significant quantities is also presented hypersthene.

Is typical associations of accessory minerals constituted from zircon, monazite, garnet, apatite, magnetite, and ilmenite, which, with some exceptions, are present almost in all petrology varieties. It is significant that in the oldest rocks of the gneisses formation (dominate biotiteamphibole-hypersthene plagiogneisses) of early Archean age, monazite-one of the most important minerals in geological formations of the basement from area that contains rare earths-was found only occasionally, and zircon is found in form of small isolated grains in relatively small quantities in almost all varieties of gneisses and crystalline schists. As an accessory mineral, monazite frequently occurs in mineralogical composition of the ultrametamorphic varieties of enderbite and alaskite formations.

We would like to pay attention to the fact the majority of zircon grains, which are in ultrametamorphic rocks composition, have round forms with melting traces of the 


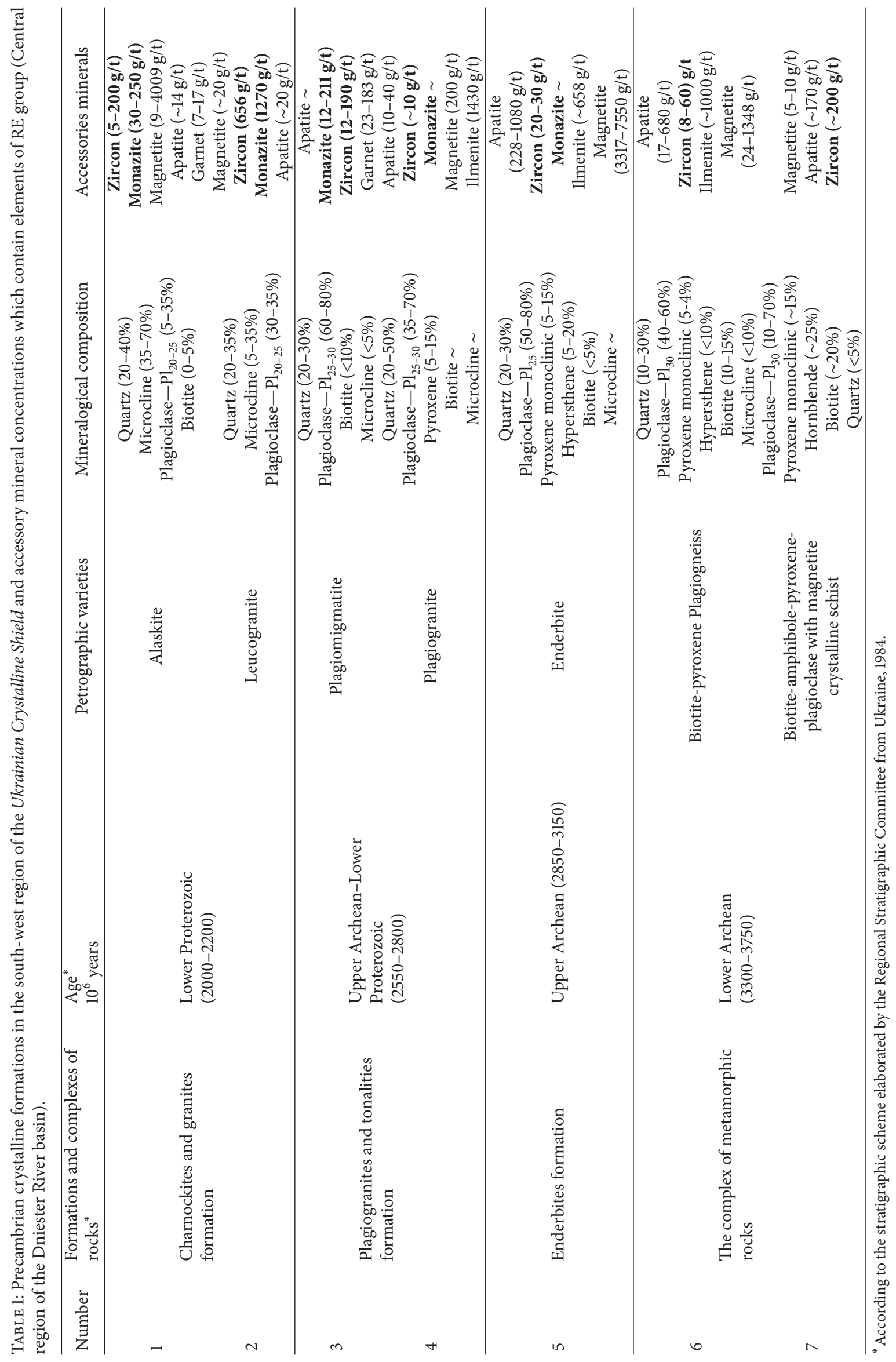


external zones. Perhaps, because of higher refractory properties, this accessory mineral passed from older geological formations in the younger ones without essential changes that are imposed by anatexis and palingenetic processes. Probably it also refers to monazite present in the same varieties of rocks. It produces the impression that multiple acts of progressive metamorphism, ultrametamorphism, and retrograde metamorphism that took place during an enormous period of geological time and modified in a cardinal way all petrologic varieties of the platform basement, and did not influence the redistribution in underground space of zircon and monazite. The above-presented affirmation is supported by geochronological research data, achieved through the radiological methods by Ukrainian geologists. In the regions of Ukrainian Crystalline Shield slope-adjacent area of Dniester River basin, monazite and zircon in rock composition from formations mentioned above practically have one and the same Archean age [11].

Many authors link the formation of concentrations of $\mathrm{RE}$ elements in the Dniester region, with the presence of accessory monazite and zircon, which are present in composition of different petrologic and lithological varieties of late Archean, early Proterozoic, and Vendian ages [5]. Remarking the high correlation coefficient between zircon and monazite $(\rho=0.73)$ and satisfactory degree of correlation $(\eta=$ $8.6>3$ ), we can assume that these two minerals in terms of geology are syngenetic and probably as accessory minerals were formed at the same time in one and the same petrological formation. At the same time, we would like to emphasize that monazite in the complex composition of metamorphic rocks of early Archaic age practically was not found. On the basis of the data from previous mineralogical and geochemical researches it was determined that monazite weight in geochemical aureoles formation (RE-elements) is much higher than that of zircon [12]. We would like to note that between crystalline and terrigenous formations in this area in quite small quantities can also be found other minerals containing rare earths (xenotime and allanite) [10].

Most of rare earth minerals, including zircon and monazite, are constituents of granite and nepheline-syenite pegmatites. There are known endogenous deposits of the rare earths which are in geological-genetic relations with alkaline granites, intrusive alkaline ultrabasic rocks, syenites (rich in pyrochlore), and pneumatolytic hydrothermal formations. If we examine the mineralogical compositions of the metamorphic and ultrametamorphic rocks varieties in the central region of the Dniester River basin, we will observe that in these types of crystalline rocks in no way can form paragenetic associations with minerals which contain rare earths [9]. It is possible that accessory mineralization of zircon and monazite has no directly bearing to the origin of formations from this area, but can be part of some blocks of the earth's crust, from neighboring regions. For example, in different regions of the Ukrainian Crystalline Shield (Jitomir, Vinita), in alkaline granitic and pegmatite rocks with monazite and zircon were found significant concentrations of RE elements (Lanthanum, Cerium, and Neodymium) [13].

From the above-said results that the issue of minerals' origin (especially of zircon and monazite) which contain rare earths, found in different varieties of crystalline rocks in the south-western East European Platform, remains open.

In terms of fundamental geotectonic concepts, the oldest parts of the continental earth crust-crystalline shieldsduring the geologic time underwent several cardinal tectonic modifications [14]. Therefore, it is presumed that in the tectonic cycle of the White Sea (Archean) the manifestations, which are well observed in the Baltic Crystalline Shield formations, ended with intensive folding, metamorphosing, and profound granitization phenomena. For corresponding geological epoch is characteristic the formation of some granite-gneiss domes, delimited in the initial phase by linear zones, consisting of volcanogenic-sedimentary rocks. At present, these linear areas are transformed into relatively narrow synclinorium, formed of profoundly modified rocks in different metamorphic facies. As a result of the epi-Archean tectonic processes (until early Proterozoic), we can assume that in such synclinorium took place several epeirogenic movements of crystalline basement, concomitantly accompanied by various destructive processes. Consequently, in certain places emerged aulacogens delimited by lineaments within which are found many remains of Archean blocks and areas with well-pronounced progressive and retrograde metamorphism manifestations. A similar structure could be the Dniester Fault which, de facto, represents a segment of Podolian Tectonic Faults Zone [15] and which delimits in the south-western part another crystalline shield of East European Platform-Ukrainian Crystalline Shield. Tectonic phenomena of early Proterozoic period ended with the consolidation of the crystalline basement from region. In subsequent geological periods the tectonic activity gradually reduced to minimum, introducing in the Dniester-Prut interfluves region only some structural changes genetically linked to the evolution of Dniester Fault. For example, in Riphean, around 950 million years along the Podolian Tectonic Faults Zone in a relatively weak process of continental riftogenesis occurred alkaline lava flows, in the result of which lenticular bodies of diabases were formed.

Manifestations of effusive or intrusive magmatism in Archean-early Proterozoic in the central region of the Dniester River basin have not been determined. It is possible that ultrametamorphic processes that took place in this region in late Archean-early Proterozoic probably "retouched" completely initial igneous rocks in the area. Consequently, we can say that zircon and monazite in the initial stages of geologicstructural formation of pericratonic region of south-western part of East European Platform were already formed and were part of the composition of pre-rocks.

As mentioned above, most endogenous deposits of RE are genetically related either with alkaline granites intrusions or alkaline typical intrusions. Examining the contribution of magmatism in the evolution of earth crust, it is determined that the alkaline magmatism events began about 2.5-2.7 billion years ago, and in an intensive way developed in Phanerozoic and arrived to maximal action in the Mesozoic. In general, alkaline rocks older than 2.7 billion years in the earth crust formations have not been found [16]. Thus, it may be deduced that the origin of zircon and monazite detected in geological formations in Dniester region in no way can be 
linked with alkaline intrusions, which may have been formed in the Ukrainian Crystalline Shield.

It is obvious that these minerals were formed however in a magmatic process unexplained so far by geologists interested in the rare earths in the area, and the issue of RE origin in composition of metamorphic and ultrametamorphic rocks of the crystalline basement in the south-western part of East European Platform requires a serious investigation to be solved.

There exist industrial concentrations of RE minerals both of endogenous type and metamorfogenic one. Rare earth deposits related to metamorphic formations are characterized by relatively homogeneous distribution of RE elements on areas of significant extension and are presented in generally by migmatites, gneiss, and metamorphosed conglomerates with monazite of other origin. It is not excluded that in the geological formations of the crystalline basement are present accumulations of monazite (and zircon) located in plagiomigmatites and leucogranites which have a rather large distribution in the Dniester region.

\section{Sedimentary Formations and Detection Premises of Concentrations of Rare Earths Elements}

4.1. The Types of Hypergen Deposits of Rare Earths Elements. Rare earths minerals of exogenous origin until now are not known. At the same time, most rare earth deposits exploited at present are of exogenous type.

According to systematization of useful mineral deposits types [17], hypergen deposits of RE are grouped into three types:

(1) residual, which are formed as a result of alteration of granite, syenite, nepheline-syenite rocks rich in monazite, sphene, pyrochlore, thorianite, cerianite, and formation in erosion crust of a zone rich with RE of cerium subgroup, $\mathrm{Nb}, \mathrm{Zr}$, Th, and $\mathrm{Y}$;

(2) sedimentary-detrital: (a) alluvial lands formed from concentrations of stable minerals in hypergen zone such as monazite, ilmenorutile, zircon, uranothorite, (b) eluvium-adobe lands with high concentrations of xenotime, pyrochlore, fergusonite, thorite, and (c) mineral lands of coastal areas consisting of significant accumulations of monazite, ilmenite, rutile, and zircon;

(3) sedimentary and sedimentary-biogenic: (a) phosphorites, (b) sands rich in RE minerals, (c) shales, and (d) fossil reminiscences.

Referring to the territory in northern and north-eastern part of Republic of Moldova, in the basal layers of sedimentary cover may be present the RE deposits such as detrital sediments. This confirms the results of recent geologicalgeochemical researches carried out in the last decades of the last century $[7,18]$.

In hypergen area monazite is a quite stable mineral. Being resistant to the action of exogenous agents, it is not broken down and in the following way in rubbly grains, is kept very long periods of geological time. Therefore, the monazite present in crystalline rocks of Archean and early Proterozoic age is also found in sedimentary rocks of platform cover in the central region of the Dniester River basin. Since the specific weight of monazite is quite high (exceeding $5.0 \mathrm{~g} / \mathrm{cm}^{3}$ ) in the erosion process of rocks with accessory monazite and further sedimentogenesis of disintegrated material, often are formed mechanical aureoles of this mineral. Therefore, it is explained that the monazite in detrital sedimentary layers may be present in concentrations much higher than its concentrations in the syngenetic rocks.

For example, in a drilling for geological mapping dug in the south of the marked territory in Figure 1 has been detected a geochemical anomaly with maximum concentrations of lanthanum $(0.1 \%)$ and cerium $(0.08 \%)$ generated by monazite, the concentration of which in basal layers of the sedimentary cover varies between 0.5 and $21.8 \mathrm{~g} / \mathrm{t}$ [10].

In a similar process are also formed the mechanical aureoles of zircon.

Sedimentary cover in central region of the Dniester River basin is made up of several complex beds, placed almost horizontally. In terms of geochronology, of lithological composition, of sedimentation conditions and diagenetic processes in slope cover of southwestern part of the East European Platform are identified four formations and sedimentary rock complexes: Vendian Formation, Ordovician-Silurian stratigraphic Complex, Cretaceous Formation, and Neogene Formation (note: currently in many countries the name of stratigraphic unit Vendian is replaced with Ediacaran, but in Republic of Moldova so far remain the same names of stratigraphic units used in Russia).

Ordovician-Silurian beds, consisting prevailingly of limestone-dolomite varieties, limestone-siliceous rocks of Cretaceous and diversity of limestone, sand, and clay varieties of Neogene age, in terms of the problem approached in this chapter, unlike the Vendian basal layers of sedimentary cover, do not present any practical interest.

By direct comparison it was demonstrated that the geological section of Podolian Vendian is stratotype almost for all formations of this age opened in different regions of the East European Platform. Thus, Vendian age layers situated in natural cropping or crossed by drilling in the north and north-eastern zone of Republic of Moldova, present a southeastern fragment of Podolian Vendian and, in a natural way, without assumptions the stratigraphic scheme of Ukrainian geologists can also be applied in the Dniester river basin conditions. For a rather complete documentation about Vendian Formation in the region, we make reference to a quite ample synthesis work prepared by Ukrainian geologists for The Third International Symposium on Cambrian System (Kiev, 1990) [19].

4.2. Camenka Formation. Directly on the surface of crystalline basement are laid-down in the deposit the layers of Camenka Formation constituted of basal conglomerates and diabases probably of Riphean age. The formation body (average thickness about 20 meters) has a lenticular-flat 


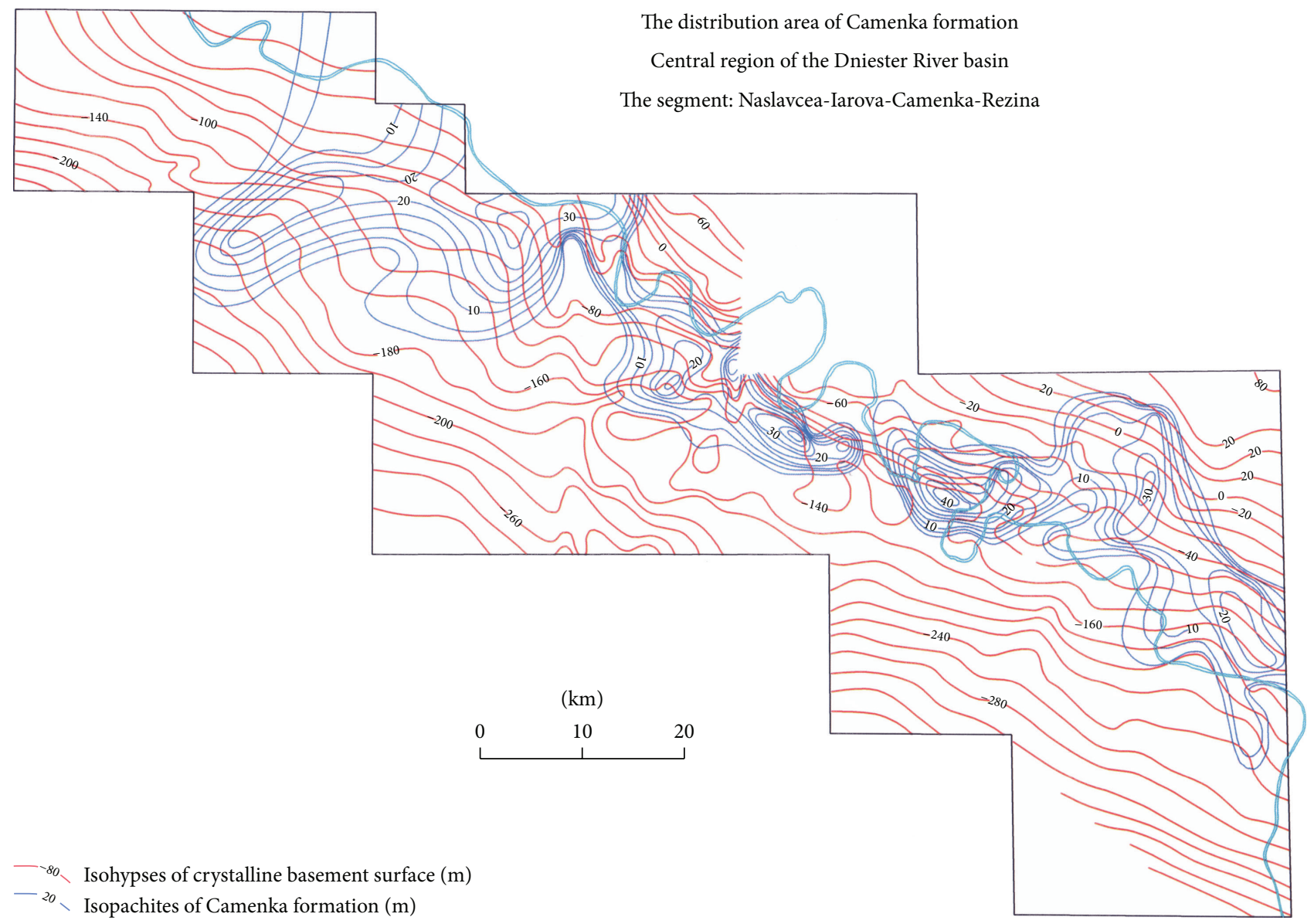

Figure 2: The distribution area of Camenka Formation in the central region of the Dniester River basin [13].

aspect, is relatively narrow (8-10 kilometers in cross section), is oriented in a north-western direction, and covers the linear-depressive zone of Dniester Fault (Figure 2). We can assume that the centers of lenticular forms coincide with channels through which on the earth surface poured lava with alkaline composition, specific for early stages of continental riftogenesis. The phenomenon took place in later Proterozoic in one of the last phases of tectonic activity in south-western areas of the East European Platform.

Camenka Formation consists of diabases and a basal layer of microconglomerates and conglomerates (Soroca Beds).

Lithological varieties of Soroca in the spread region of Formation Camenka do not present an integral structural unit. Firstly, these lithological varieties are in deposits just in the spread zone of diabases and only in some places vulcanites of Camenka Formation are laid-down directly in deposit on the surface of crystalline basement. Perhaps Soroca basal beds in the mentioned region had had a much large spread but because of denudation processes were preserved only under diabases. Thickness of Soroca Beds crossed by drilling mapping varies from 0.5 to 3.5 meters. Rocks are distinguished by their mineralogical composition and are formed from an unselected rubbly material: conglomerates, conglomerate-breccias, microconglomerates (predominant), coarse-grained sandstones, and arkose sandstones (rarely).
The rubbly material is presented by slightly rounded grains of crystalline basement rocks-quartzite, potash feldspar, and biotite scales, cemented with a brown argilitic material. Cement volume typically exceeds $50 \%$ by volume. In the following way, most of Soroca Beds' rocks differ by their specific brown color.

Arkose sandstones and microconglomerates that can be found in the composition of the basal layers of Camenka Formation are massive rocks, hard, of gray-green or pink-gray color, have sabulous structures, and consist of plagioclase (up to $50-60 \%$ ), potash feldspar (up to $15 \%$ ), quartz (25 to $35 \%$ ), cement, and grains of basement rocks.

In clastic material are prevalent semirounded or rugged forms, and grains' sizes range from 10-15 millimeters (microconglomerates), 1.0-0.1 millimeters (sandstones), 0.1 millimeters (sandy mudstones). Cement has a high porosity and has a kaolin-hydromicaceous, kaolin-chloritehydromicaceous, or kaolin composition.

From accessory minerals are present small grains of garnet, zircon, monazite, apatite, and titanomagnetite.

The rocks of Soroca Beds have a specific radioactivity relatively high (30-35 microns/hour) imposed by the presence of isomorphic thorium in the monazite composition.

Based on geochemical investigations of Soroca microconglomerate were found relatively high concentrations of La. 


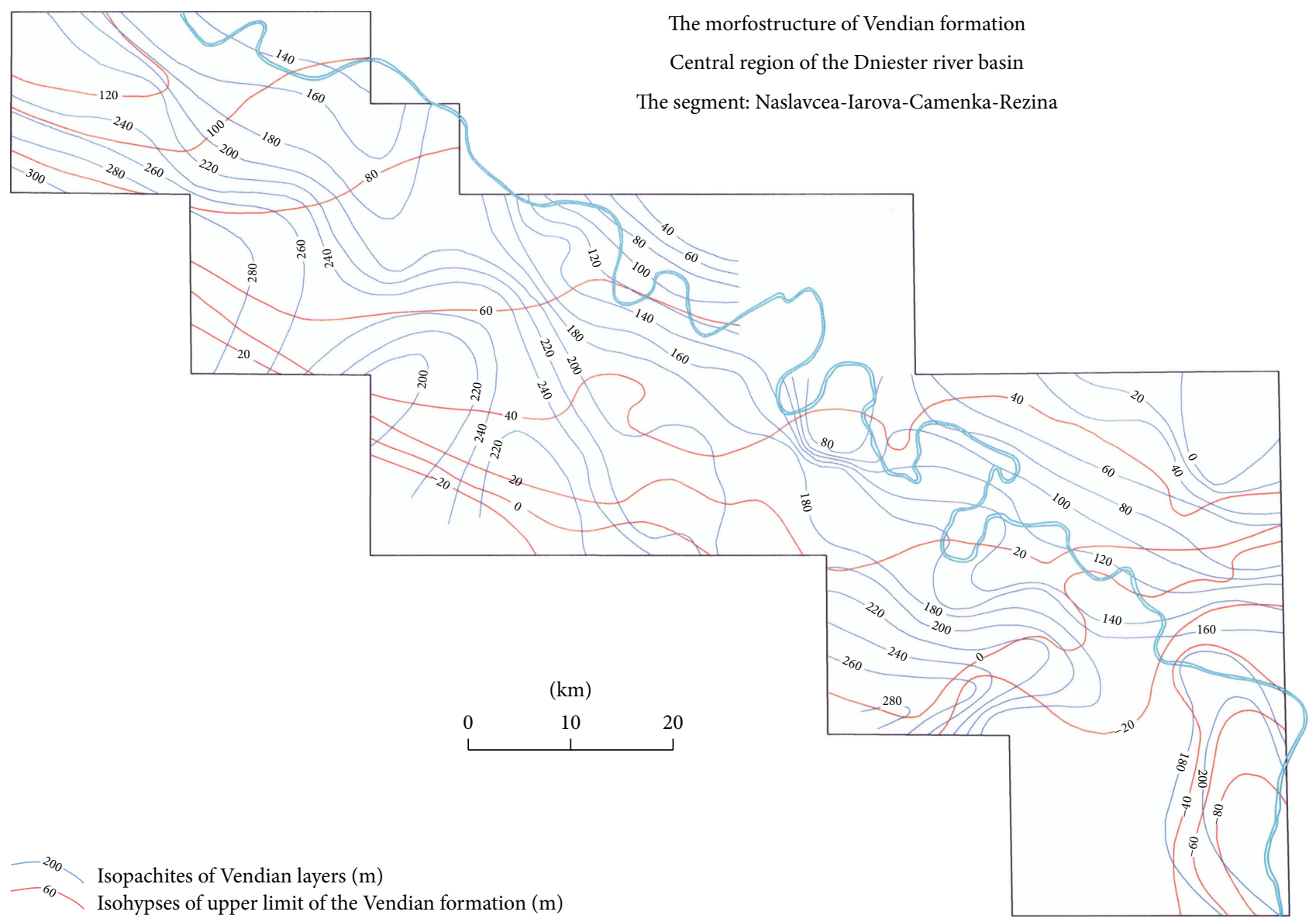

FIgURE 3: The morphostructure of Vendian Formation in the central region of the Dniester River basin [13].

Diabases predominate in Camenka Formation and in axial zone of the banded body exceed the thickness of 30$40 \mathrm{~m}$. In macroscopic point of view diabases are compact volcanogenic rocks of a dark gray, gray-brown, or dark greenish color with a relatively high specific weight. Their structure is cryptocrystalline or crystalline in very small grains. Between diabases discovered in the Dniester area there are two varieties-aphyric diabase and diabase with an apparently porphyric texture. Usually porphyric inclusions have various sizes (1-15 millimeters) and consist of calcite and, rarely, chlorite. Most diabases have an ophytic structure and massive texture, and in their composition are included basic plagioclase (40-50\%), monoclinic pyroxene (5-19\%), chlorite (30-35\%), epidote (3-7\%), and titanomagnetite $(5-10 \%)$. The minerals which contained RE elements in Camenka Formation were not detected.

4.3. Terrigenous Layers from the Vendian Lower Level. According to the stratigraphic scheme used by Moldavian and Ukrainian geologists [20], the formations of Vendian age are differentiated in series, which include several beds. In normal sequence Moldavian Vendian is composed of Olchedayev Beds $\left(\mathrm{V}_{\mathrm{ol}}\right)$, Lomozov Beds $\left(\mathrm{V}_{\mathrm{lm}}\right)$, Cosauti Beds $\left(\mathrm{V}_{\mathrm{ks}}\right)$, Lyadova Beds $\left(V_{l d}\right)$ Bernashevka Beds $\left(V_{b r n}\right)$, Bronnitsa Beds $\left(V_{b r}\right)$, Zincov Beds $\left(\mathrm{V}_{\mathrm{zn}}\right)$, Dzhurzhevka Beds $\left(\mathrm{V}_{\mathrm{dz}}\right)$, Kalyus Beds
$\left(\mathrm{V}_{\mathrm{kl}}\right)$, Pilipy Beds $\left(\mathrm{V}_{\mathrm{pl}}\right)$, and Shebutintsy Beds $\left(\mathrm{V}_{\mathrm{sb}}\right)$. All these local stratigraphic units are composed of terrigenous varieties: sandstones, aleurolites, mudstones, tuffaceous clay stone, and greenstones (Table 2).

The majority of layers, almost completely, can be studied either in outcrops in northern part of the republic, either in mapping drilling cores, dug in areas covered by Paleozoic, Mesozoic, and Cainozoic formations.

In the region between Dniester and Prut Rivers, Vendian layers are laid-down directly in deposit on the surface of crystalline basement and the central region of Dniester River basin-partially on the Camenka diabases and Volyn Series microconglomerates.

The lower limit of Vendian Formation in the Dniester river region has a dipping oriented to southwest $\left(210-220^{\circ}\right)$ and dipping angle varies around the $40^{\prime}$ (Figure 3 ). It should be mentioned that the basement relief can be observed in geomorphologic elements that are in direct connection with the principal faults in the Dniester region. The upper limit of Vendian Formation in the Podolian Tectonic Zone with a small dipping to south-south-western is disposed practically horizontally, and in the south-western of mentioned territory in this chapter, the lower limit is the same direction southsouth-western dipping with an angle about $20^{\prime}-30^{\prime}$. By this small difference between the dipping angles of geological 


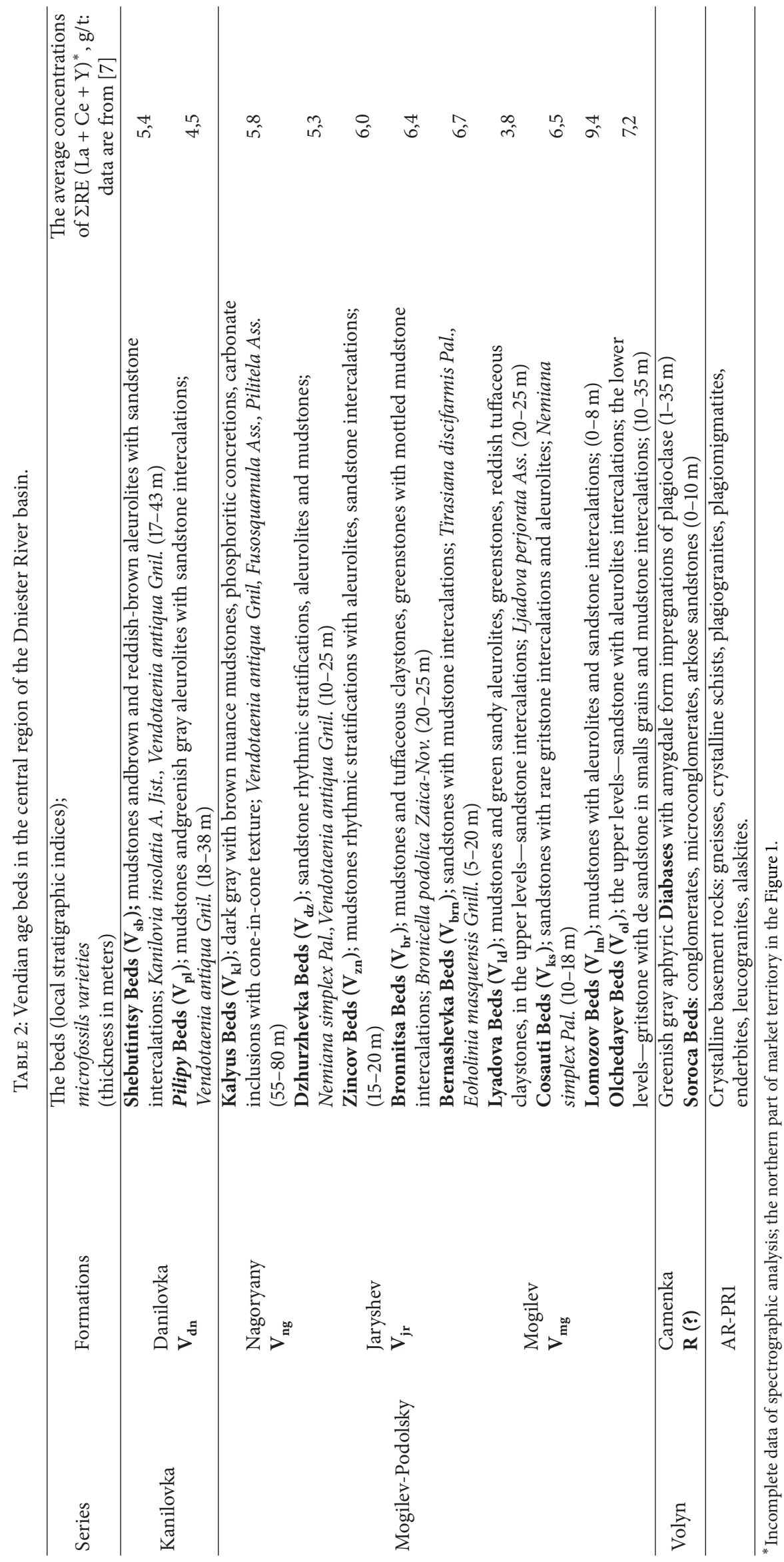


limits is explained the slow increase of the thickness of Vendian Formation that in immediate nearness of Predobrogean Depression exceeds 750-800 meters. In contrast with lower limit, the surface of upper limit of Vendian was subjected to relatively poor processes of denudation, which changed the morphostructural aspect appeared after the end of sedimentogenesis processes.

As a result of geochemical investigations it was established that in the lower layers of Vendian Formation the concentration of RE elements compared with layers of upper levels is relatively higher (Table 2). In particular it refers to Olchedayev, Lomozov, and Cosauti Beds of Mogilev Formation. For example, in the southern part of the territory in Olchedayev Beds was detected an anomalous zone with quite high concentrations: $C_{\mathrm{La}}=0.1 \%$ and $C_{\mathrm{Ce}}=0.08 \%$ [10], which exceed the geochemical background that is approximately the same as for Lanthanum and for Cerium.

In terms of perspective of detecting some significant concentrations of RE elements, as a result of formation of mechanical aureoles consisting of zircon and monazite, Olchedayev, Lomozov, and Cosauti beds represent an object for much more detailed geological and geochemical researches.

Olchedayev beds are composed by detrital sedimentary rocks in big grains (varieties of conglomerates, microconglomerates, and sandstones) and mudstones or sandy mudstones, present in the layer's body in form of relatively shallow intercalations.

Geological section of Olchedayev beds is not stable throughout the whole distribution area, but in terms of lithological varieties, which form layers and the complex stratifications of this local stratigraphic unit, it is observed a relatively constant accordance: in the lower levels are present microconglomerates, and in the upper ones-gritstone in big grains. Specific for Olchedayev layers is the presence of a layer of clays and sandy clays which separate the microconglomerates from gritstone.

Geological section of Olchedayev beds constructed on basis of mapping drillings in the southern part of the marked territory in Figure 1 is presented in the following way.

Directly on the altered surface of diabases of Camenka Formation or on crystalline basement surface crust practically devoid of erosion crust are laid-down.

(1) Microconglomerates of brown color with angular grains of quartz, potash feldspar, and diabases (up to 20-25\%); the color is imposed by clayish cement rich in iron hydroxides; the thickness of this basal layer varies around 4 meters.

(2) Rhythmic intercalations of arkose microconglomerates with sandstones in various grain of gray or graygreen color; in both lithological varieties are present inclusions of sandy clay stones and clay stones; layer thickness-about 7 meters.

(3) Dark gray microconglomerates with clastic grains of quartz and potash feldspar; microconglomerate cement is clayish, and their thickness is 1 meter.
(4) Greenish-brown and brown mudstones with thin intercalations of fines sandstone and sandy clay stone; thickness: 4.5 meters.

(5) Gray and gray-reddish arkose gritstones with isolated inclusions of quartz and potash feldspar (some grains reach up to 5 millimeters in diameter); between the sandstones are found rare and thin intercalations of dark gray mudstones; thickness average: about 7 meters.

(6) Gritstones of dark gray color with clayish cement; thickness not exceeding 4 meters.

(7) Quartz-feldspar, gray and light gray sandstones in different grain, including coarse grains; are visible horizontal and oblique stratifications of different granular fractions; sandstone thickness: 5.0 meters; on the quartz-feldspar sandstones are laid-down the Lomozov Beds.

The most common thickness of Olchedayev layers varies around 25 meters.

Sandstones and gritstones of Olchedayev Beds in the upper regions of geological section are of light gray color. In lower areas, depending on potash feldspar quantities, the color has reddish hues. In microscopic sections are observed sabulous, silitic, or mixed structures (sabuloussilitic); cement structure is silitic. In terms of composition, the rocks range from quartzose and arkose varieties. Amount of feldspars (potash feldspar prevailed), in most cases does not exceed $50 \%$ by volume. Both in the microconglomerates (also highlighted) and in the sandstones are frequent isolated grains of quartzite and rocks of crystalline basement. In the lower levels of Olchedayev layers are found frequently small scales of biotite.

The degree of grains rounding from which are formed the terrigenous rocks varieties of Olchedayev increases with their size: coarse grains are round and smooth, small grains are ragged. Often microconglomerates cement is amorphous mass clayish, which together with rock grains imposed porosity quite evident.

Accessory minerals in small quantities are presented by garnet, zircon, and monazite. A minus of geological research carried out in the mentioned region in this chapter consisted in that a mineralogical analysis which would determine the quantitative relations between zircon and monazite was not achieved. As we have remarked, the origin of mineralization rich in RE elements in geological formations from the Dniester basin region is a great problem. Additional information which would facilitate the solving of this problem, would present the thorough study of the separate grains of zircon and monazite from the structure and composition, and would be extremely important in terms of geochronology. It is possible that the absolute ages of zircon and monazite should coincide with the ages of these minerals found in crystalline formations of basement. It did not exclude the case that these minerals are different as assortment of isomorphic elements in their chemical composition. Such research are important for solving of various fundamental and practical geological problems which can determine the origin of zircon and 
monazite, the sedimentogenes processes and the formation of mechanical aureoles with significant concentrations of useful components. Unfortunately, because of changes that have intervened in the last decade of the past century in the Republic of Moldova, all expensive geological research was suspended.

In the Olchedayev rocks are found rare impregnations of galena, barite, fluorite, and xenotime $\left(\mathrm{YPO}_{4}\right)$. Because monazite and zircon are contained isomorphic impurities of Th and $\mathrm{U}$ and xenotime-about $5 \% \mathrm{UO}_{2}$-Olchedayev Beds are characterized by a relatively high radioactivity, which rarely reaches up to 500 and 780 microns/hour.

Lomozov beds are formed preponderant from mudstones a dark gray color with mica; they are intercalations of sandstones finely dispersed. The layers thickness has not been exceeding 5 meters. In some places Lomozov rocks are missing. At level of Lomozov Beds is identified a complex layer, composed of very fine stratifications of fine-grained sandstone and of dark gray mudstones relatively rich in minerals containing RE. Because the average concentration of $\mathrm{La}+\mathrm{Ce}+\mathrm{Y}$ amount, compared to other Vendian stratifications, is the largest-9.4 g/t (Table 2).

The mudstones consisted of an amorphous mass of gray color, and in microscopic sections brown color, with abundant additions of small scales of hydromica, disposed parallel with surfaces of sedimentation. On the fund of this based mass are detected small granules (silitic) of quartz with angular forms. In Lomozov Beds have a specific character, in the mudstones composition are often presented inclusions of biotite and more rarely of muscovite as elongated scales.

Cosauti Beds, in lithological point of view of this local stratigraphic unit, are relatively homogeneous and are composed almost solely of sandstone. Dark mudstone intercalations and dispersed fine sandstone are marked only in patches. Cosauti sandstones have white color with sugar aspect, in a homogeneous medium or small grain.

In microscopic sections sandstones are psammitic clear structure. Aleurite fraction ( 0.1 millimeters) is about $5 \%$ by rock volume (rarely-10-12\%). Large grains of quartz are frequent (about 2 millimeters), embedded in argillitesandy mass (a few tenths of a percent), but in granulometric point of view, sandstone are very well sorted. In the Cosauti beds were discovered sandstone consist not only of quartz grains. Quartzose varieties usually contain about $10 \%$ of detrital material, consisting of other minerals. The quartzfeldspar and arkose sandstones are predominated, in which the feldspar grains scant of above 20\% (potassium feldspar is prevailing). It is common inclusions of biotite in the form of scales, about $1-2 \%$ from volume. Less commonly in the rock small granules of quartzite are found. In small isolated granules can be identified pyrite and magnetite. Accessory minerals are more frequent in zircon and monazite, which generated geochemical anomalies with relatively high concentrations of REE.

Cement of Cosauti sandstones is relatively varied: chlorite-hydromicaceous (sometimes with added of kaolin or dikkite), silica or carbonated in which predominated calcite. The thickness of Cosauti Beds varies between 10 and 18 meters.
Compared with Olchedayev and Lomozov Beds, varied by mineralogical and granulometric composition, Vendian section above Cosauti sandstones are relatively homogeneous on all distribution area. A certain practical interest would present the mudstones of Kalyus Beds rich in phosphoritic concretions.

The morphostructure of Olchedayev, Lomozov, and Cosauti beds succession $\left(\mathrm{V}_{\mathrm{ol}}+\mathrm{V}_{\mathrm{lm}}+\mathrm{V}_{\mathrm{ks}}\right)$, in the Dniester region are presented quite homogeneous. In terms of tectonic, the main structural element within the mentioned territory in this paper are presented by a segment of Podolian Faults Zone, oriented in north-western direction, and called by autochthon geologists, Dniester Fault (Figure 1). Effusion magmatism with alkaline lava flows were distinguished the beginning of a continental riftogenesis which was manifested in later Proterozoic. As a result of geological mapping, it has been shown that the basement along the Dniester River has a narrow linear structure with typical features of rift valley in which vertical dislocations amplitudes of basement blocks varies within 20-60 m [2, 3, 7, 10, 18]. Completed by the Camenka diabase this structure in sedimentary cover layers does not reflect practically anything. This is observed by comparison of the crystalline basement relief shown in Figure 2 with the surface of lower limit of Vendian Formation (Figure 4), the latter being much smoother. The crystalline basement relief and the surface of lower limit of Vendian Formation are observed linear zones oriented in transversal directions Dniester Fault, which occurred in result of the tectonic process much earlier-in the south-west of pericratonic zone of the East European Platform, late Archean was formed a several tectonic faults oriented in preponderantly north-eastern direction [10]. Perhaps, along these faults had occurred more intensive erosion processes that had been led to digging in the Archean relief, negative linear forms.

In the following way is explained the morphostructural aspect of the succession beds which are at Vendian based in the central region of the Dniester River basin. Examining the summary thickness of Olchedayev, Lomozov, and Cosauti Beds, we see a series of relatively isometric areas which have comparatively larger thickness which is in correlation with some earlier faults (Archean) in the region (Figure 4). Accordingly, we conclude that the geological research in detection purpose of eventual essential accumulation of RE elements should be continued in these areas with relatively larger thickness of Vendian basal layers.

\section{Conclusion}

(1) As a result of geological mapping in the basal layers of Moldavian Vendian at accessible depths for an eventual exploitation has been located REE mineralization. At the same time, the prospect of these layers, in the detection point of view of some industrial accumulations of ores so far not has been resolved. Consequently, in the opinion of many explorers, studying of Vendian rocks needs to be continued until getting a univocal solution.

(2) In terms of the geological formations of the central region of the Dniester river basin, the minerals presented a practical interest in terms of the formation of significant 


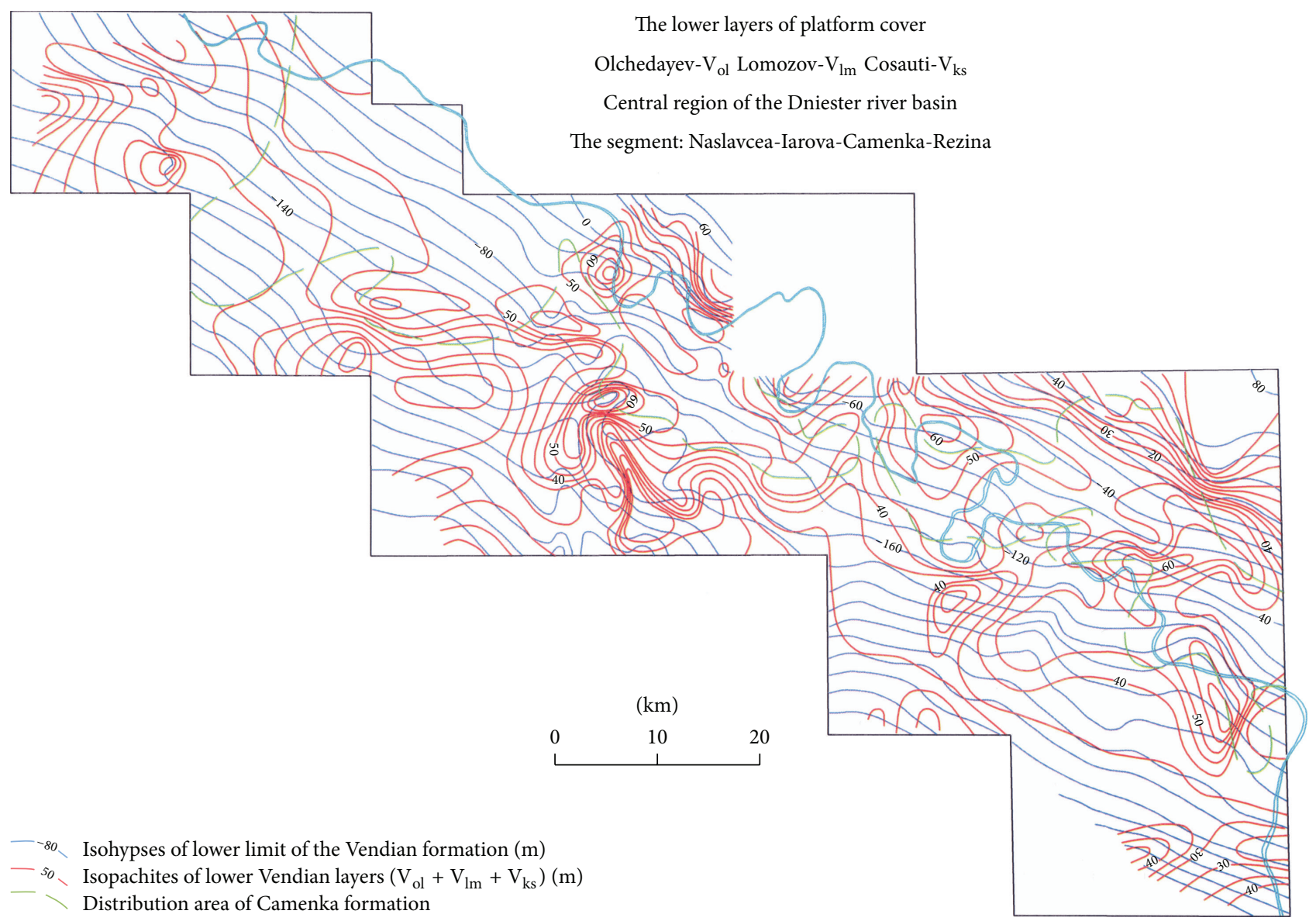

FIgURE 4: The lower layers of platform cover, Olchedayev $\left(\mathrm{V}_{\mathrm{ol}}\right)$, Lomozov $\left(\mathrm{V}_{\mathrm{lm}}\right)$, and Cosauti $\left(\mathrm{V}_{\mathrm{ks}}\right)$ Beds in the central region of the Dniester River basin [13].

accumulation of RE elements (Sc, Y, La, Ce, and $\mathrm{Yb}$ ) are monazite (phosphate) and zircon (silicate); probably zircon and monazite are paragenetically associated.

(3) In order to locate in the underground space geochemical aureoles of the elements mentioned above, it is necessary to study carefully the conditions of migration and concentration of these elements in diverse mineralogenes processes; in conditions of the Dniester River basin-in the progressive and retrograde metamorphism, ultrametamorphism, metasomatic processes, and training processes of the basal layers of platform cover.

(4) Based on the geological and geochemical data, accumulated in the geological mapping to outline geochemical aureoles and anomalies, which may serve as a direct index of the presence in crystalline and sedimentary formations of mechanical aureoles of monazite and (or) zircon.

(5) Geological research in detection purpose of eventual essential accumulation of RE elements, in central region of the Dniester River basin should be continued in relatively larger thickness of Vendian basal layers the Olchedayev, Lomozov, and Cosauti Beds oriented along the ArcheanProterozoic tectonic faults.

(6) The geochemical study of RE elements has remarkable importance in interpretation and restoration of geological processes of the geological past. Because of this it is important to investigate concentrations of these elements in different varieties of rocks of different ages and origins. In particular it is important to establish particular paragenetic types between RE elements and other associated minerals to solve the geological genetically problems:

(i) to establish correlative links between particular types of RE elements and particular types of crystalline or sedimentary rocks;

(ii) to determine the origin of rocks which contain these elements (formed in a single magmatic process, in a common metamorphic facies, and in a single sedimentogenesis cycle).

If the detection of a deposit of zircon and monazite, containing rare earths, brings a direct practical result, geochemical study of any region of the earth crust is of high particular importance in geological prospection. Because it solves a great problem regarding the determination of paragenetic associations of minerals and chemical elements, to determine the type of petrographic provinces, specifies geotectonic appearance of territories, and to determine the links between lithogenic processes and palaeogeographic conditions in 
the zone, to resolve stratigraphic issues. Obviously, all this geological data are served primarily for resolving applied geological problems such as detection of other types of useful mineral deposits.

\section{Conflict of Interests}

The author declares that there is no conflict of interests regarding the publication of this paper.

\section{References}

[1] Geology of the USSR, Moldavian SSR, vol. 45, Nedra, Moscow, Russia, 1969.

[2] V. I. Dimo, The Geological Report on the Results of Deep Geological Formations Study Effectuated in 1965-1971 Years in the Northern Region of Moldavian Dniester River Basin, AGRM Funds, Chișinău, Moldova, 1971.

[3] I. T. Ceban, The Geological Report on the Results of Deep Geological Formations Study to Indentify Metallogenetic Perspectives Structures of the Dniester Fault Zone, AGRM Funds, Chisinau, Moldova, 1981, (Russian).

[4] P. D. Bucatciuc, The Geological Report on the Sedimentary Cover Formations of Upper Precambrian in the South-Western Pericratonic Region of the East European Platform, AGRM funds, Chisinau, Moldova, 1973 (Russian).

[5] V. Ciobotaru, "General considerations on the Dniester-Prut interfluves geology, especially of the north-eastern region of Republic of Moldova," in Scientific Annals of Moldova State University, Series: Chemical-Biological Sciences, pp. 169-174, CEP USM, Chisinau, Moldova, 2004.

[6] D. Lvina, The Geological Report on the Distribution Particularity of the Non-Ferrous, Rare, and Rare Earth Elements in Precambrian Formations from the North Moldova, AGRM Funds, Chisinau, Moldova, 1972, (Russian).

[7] A. Zaharov, Geological Structure and Useful Mineral Deposits in the Central Region of the Dniester River Basin (Ocnita). The Geological Report on the General Geological Mapping at 1:50000 Scales Made the Topographic Planes M-35-127-D; M-35128-C, D-b; M-35-140-A, D and Finishing the Study Geological Prospecting in General Scale 1:50,000 from Topographic Plan M35-140-D, AGRM Funds, Chisinau, Moldova, 1992, (Russian).

[8] A. V. Drumea, "Moldova," in Encyclopedia of European and Asian Regional Geology, F. M. Moores and R. W. Fairbridge, Eds., Encyclopedia of Earth Sciences Series, pp. 537-540, Chapman \& Hall, London, UK, 1997.

[9] A. V. Drumea and V. I. Canicovski, Tectonic Moldavian SSR, Academy of USSR, Moscow, Russia, 1961 (Russian).

[10] G. H. Dmitrov, Charnockites Formation of Central Region of the Bug River Basin. IGFM, Kiev, 1977, (Russian).

[11] A. Zaharov, C. Sergheev, and V. Ciobotaru, The Geological Report on the Geological Structure and Useful Mineral Deposits in Mining-Industrial Region Rezina, AGRM Funds, Chisinau, Moldova, 1987, (Russian).

[12] A. Popuiac, "General geochemistry of rare earths in the central region of the Dniester river basin, Republic of Moldova," Journal of Rare Earths, vol. 28, supplement 1, pp. 513-516, 2010.

[13] A. Popuiac, "The detection premises of useful mineral deposits in the Vendian formations in the central region of Dniester river basin," Scientific Notes of Taurida V. Vernadsky National University, Series: Geography, vol. 24, no. 63, pp. 98-105, 2011.
[14] V. E. Hain and N. A. Bojko, Geotectonic History. Precambrian, Nedra, Moscow, Russia, 1984, (Russian).

[15] S. S. Cruglov and A. K. Ţâpko, Tectonic of Ukraine, Nedra, Moscow, Russia, 1988, (Russian).

[16] L. N. Kogarko, "Alkaline magmatism in the Earths history," in The Planet Earth. The Encyclopedic Reference Book, pp. 76-81, VSEGEI, St. Petersburg, Russia, 2004.

[17] V. V. Scerbina, Geochemical Peculiarities and Deposit Types of Scandium, Gosgheoltehizdat, Moscow, Russia, 1960 (Russian).

[18] V. Ryborak, Geological Structure and Useful Mineral Deposits in the Central Region of the Dniester River Basin (Soroca). The Geological Report on the General Geological Mapping at 1:50000 Scales Made the Topographic Planes M-35-141-C, M-35-142- C, D, $D$ and Finishing the Study Geological Prospecting in General Scale 1:50,000 from Topographic Plan M-35-141-A, AGRM Funds, Chisinau, Moldova, 1990, (Russian).

[19] V. A. Velicanov, Ed., The Vendian of Podolia, Excursion Guide for III International Symposium on Cambrian System and Vendian/Cambrian Boundary, Kiev, Ukraine, 1990.

[20] V. A. Velicanov, E. A. Aseeva, and M. A. Fedonkin, Vendian of Ukraine, Naukova dumka, Kiev, 1986, (Russian). 

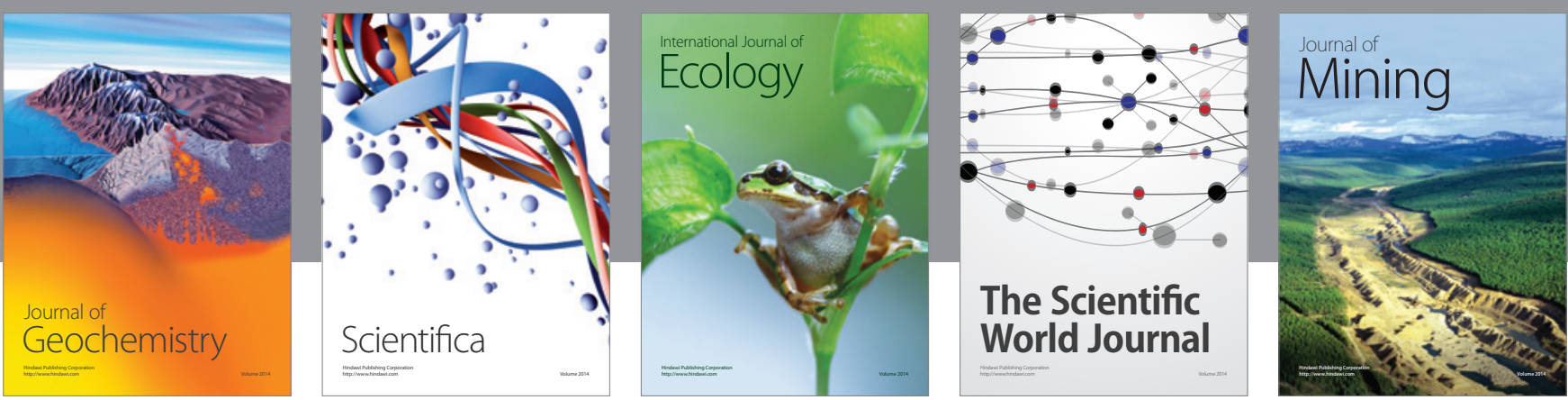

The Scientific World Journal
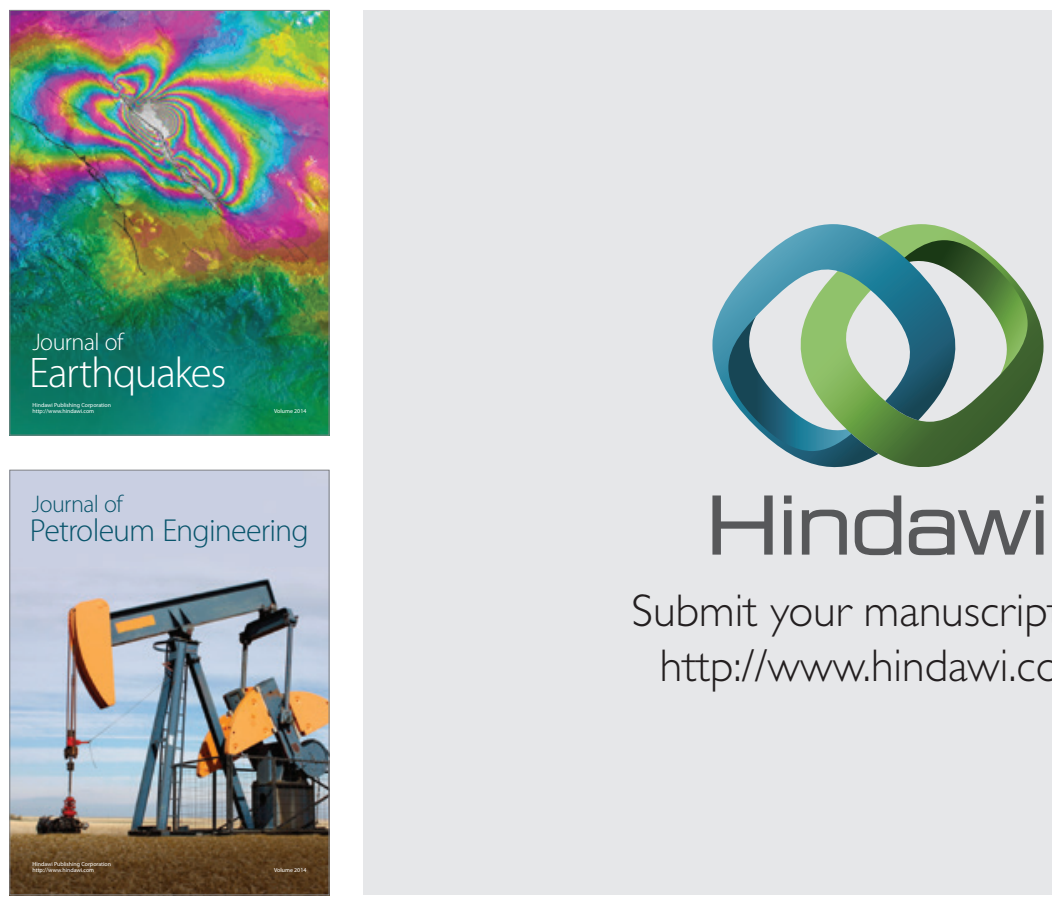

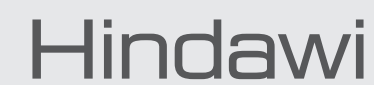

Submit your manuscripts at

http://www.hindawi.com
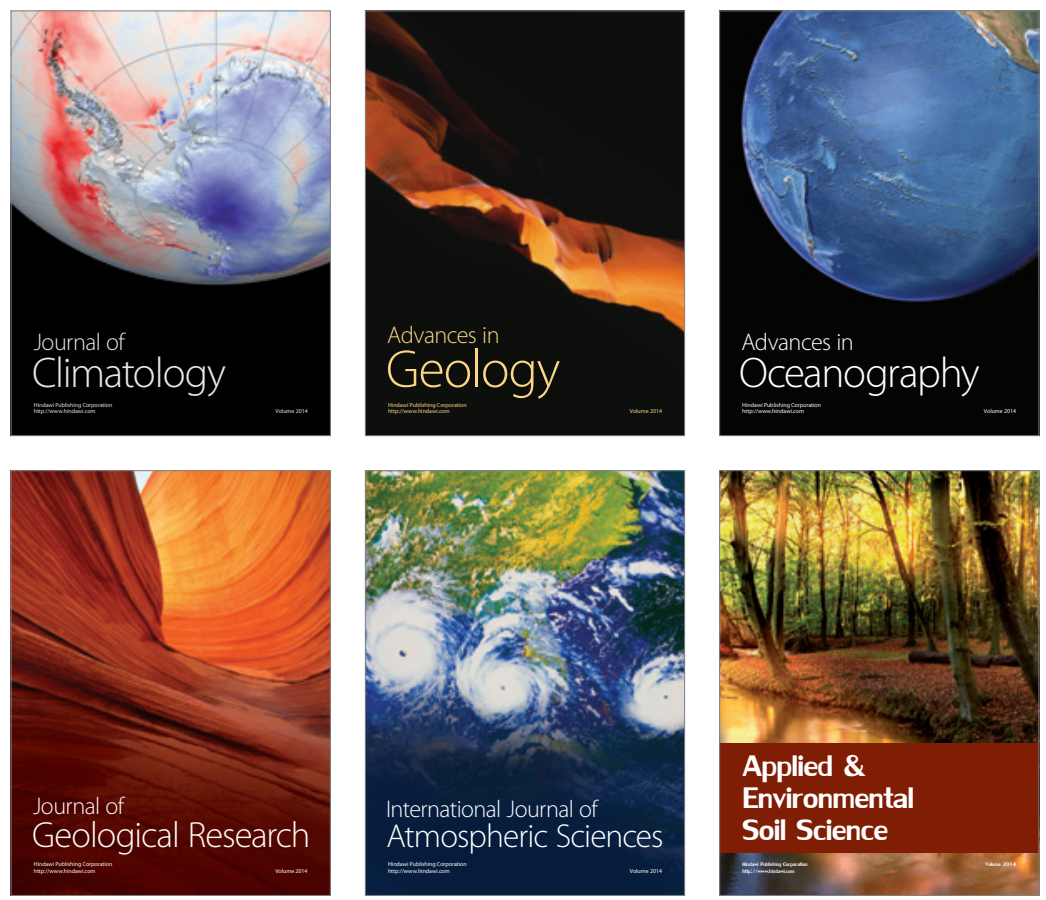
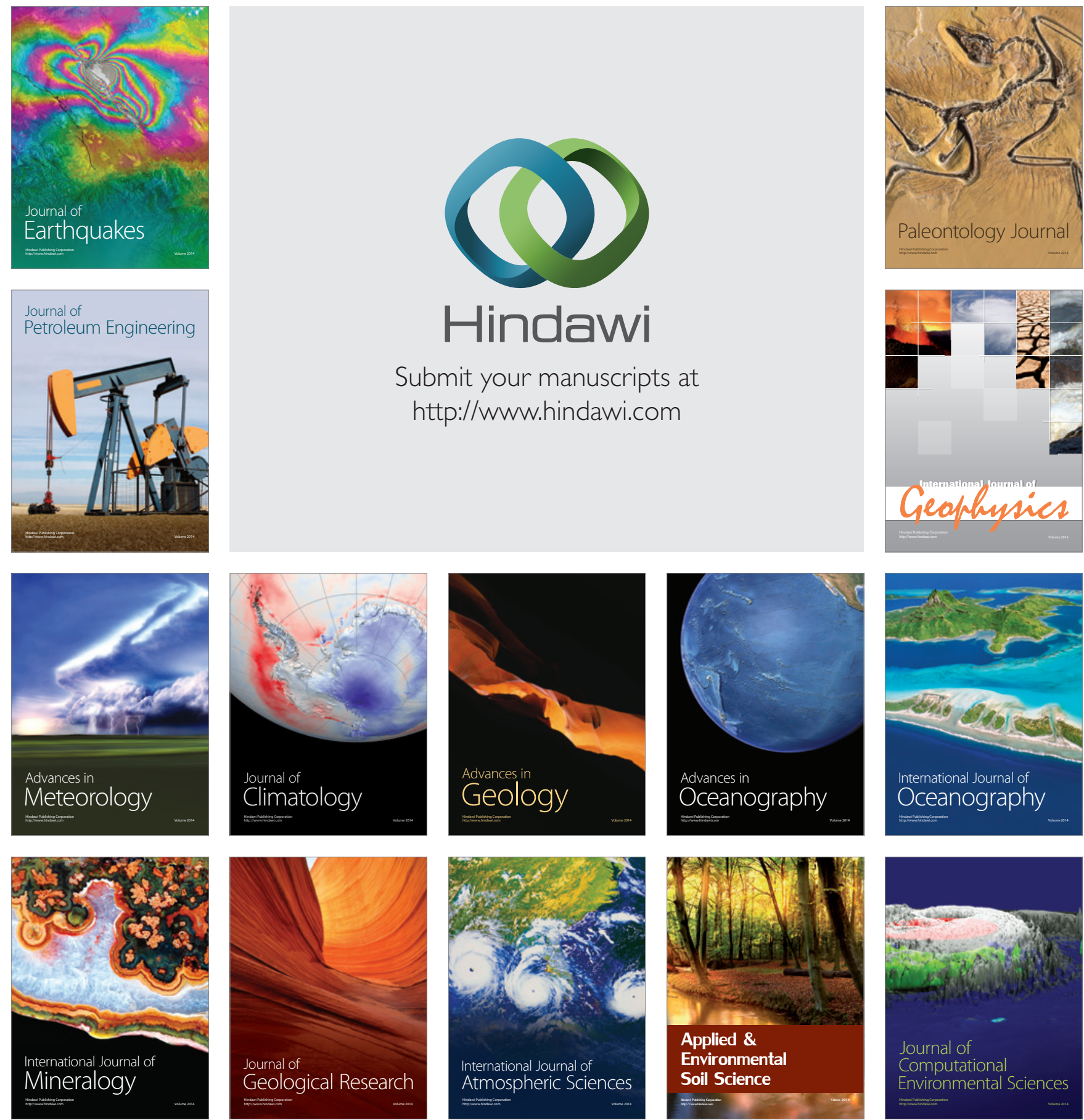